www.volsu.ru

DOI: https://doi.org/10.15688/jvolsu3.2017.2.10

UDC 338.48

LBC 65.58

\title{
RUSSIAN TOURISM INDUSTRY IN THE CONDITIONS OF ECONOMIC DEVELOPMENT CRISIS OF 2014-2016
}

\author{
Liliya V. Detochenko \\ Volgograd State Socio-Pedagogic University, Volgograd, Russian Federation \\ Natalya A. Lobanova \\ Volgograd State Socio-Pedagogic University, Volgograd, Russian Federation
}

\begin{abstract}
The article deals with the role and place of the tourism industry at the present stage in the world economy and Russian economy. The authors show the change in the ratio between the number of tourists leaving Russia and the number of foreign citizens visiting the Russian Federation with tourist purposes during the crisis 2014-2016 years. The possibilities of developing the international Russian outbound tourism are studied. The authors consider the role and place of Russia as a supplier of tourists to other countries: dynamics, factors that promote and prevent the development of international outbound travel from Russia, change of trips geography, distribution of Russian tourists by the types of tourism. The analysis is carried out, and the changes of the top ten leading countries on the reception of Russian tourists in 2014-2016 are shown. The authors mark the countries with significant growth, and the countries that show a decline in the reception of tourists from Russia. The article describes the possibilities of international inbound tourism in Russia, involvement of tourists from around the world in the tourist industry in Russia: dynamics, geography of inbound tourism, changes in the share of countries, factors affecting the visiting of Russia by foreign tourists. The analysis is carried out, and the changes of the top ten leading countries on tourist visits in Russia in 2014-2016 are shown. The authors indicate the increasing role of tourists from the Asian region - from China, South Korea, India, Iran, which are interested in different types of tourism (including recreational beach tourism) in the territory of Russia in the incoming tourist flows to our country. The features of the development of domestic tourism in the Russian Federation, the factors that promote and prevent the growth of the share of Russian domestic tourism at the present stage are shown. It is noted that, in the opinion of the authors, as early as in 2017 international outbound tourism will win back its positions from inbound and domestic tourism.
\end{abstract}

Key words: contribution of tourism to the economy, international outbound tourism, international inbound tourism, domestic tourism, tourism branch.

УДК 338.48

ББК 65.58

ТУРИСТСКАЯ ОТРАСЛЬ РОССИИ В УСЛОВИЯХ КРИЗИСНОГО ЭТАПА РАЗВИТИЯ ЭКОНОМИКИ 2014-2016 ГОДОВ

\author{
Лилия Валерьяновна Деточенко \\ Волгоградский государственный социально-педагогический университет, \\ г. Волгоград, Российская Федерация \\ Наталья Анатольевна Лобанова \\ Волгоградский государственный социально-педагогический университет, \\ г. Волгоград, Российская Федерация
}

Аннотация. Рассматривается роль и место туристской отрасли на современном этапе в мировой экономике и в экономике России. Показано изменение соотношения между числом выезжающих из России 
туристов и числом иностранных граждан, посещающих Российскую Федерацию с туристскими целями в кризисные 2014-2016 годы. Изучены возможности развития международного российского выездного туризма. Рассмотрены роль и место России как поставщика туристов в другие страны мира: динамика, факторы, способствующие и препятствующие развитию международного выездного туризма из России, изменение географии выездов, распределение российских туристов по видам туризма. Проведен анализ и показаны изменения первой десятки стран-лидеров по приему российских туристов в 2014-2016 годы. Отмечены страны, показывающие значительный рост, и страны, демонстрирующие спад в приеме туристов из России. Изучены возможности международного въездного туризма в Россию, участие туристов из разных стран мира в туристской отрасли России: динамика, география въездного туризма, изменение доли стран, факторы, влияющие на посещение России иностранными туристами. Проведен анализ и показаны изменения первой десятки стран-лидеров по туристским посещениям России в 2014-2016 годы. Обозначена все возрастающая роль во въездных туристских потоках в нашу страну туристов из азиатского региона - из Китая, Южной Кореи, Индии, Ирана, которые заинтересованы в разнообразных видах туризма (в том числе и в рекреационном пляжном) на территории России. Показаны особенности развития внутреннего туризма в Российской Федерации, факторы, способствующие и препятствующие росту доли внутрироссийского туризма на современном этапе. Отмечено, что, на взгляд авторов, уже в 2017 г. международный выездной туризм отыграет свои позиции у въездного и внутреннего.

Ключевые слова: вклад туризма в экономику, международный выездной туризм, международный въездной туризм, внутренний туризм, туристская отрасль.

\section{Введение}

Туризм в современном мире - это отрасль, охватывающая все грани «устойчивого развития», вызывающая экономический рост территорий, способствующая занятости населения и сокращению бедности, эффективному использованию ресурсов, выработке новых принципов охраны окружающей среды, «диалогу цивилизаций» и снижению градуса напряженности на планете. По данным UNWTO, туризм интегрирован почти в 400 отраслей мирового хозяйства, предоставляет примерно каждое 11-12 рабочее место и обеспечивает в последние годы порядка 1,5 трлн долл. поступлений. В настоящее время туризм - это фактически единственная в мире отрасль, демонстрирующая стабильный финансовый рост и среднегодовое увеличение числа международных туристов на 4 \% в год [8].

На фоне успехов мирового туризма, туристская отрасль России на современном кризисном этапе развития испытывает серьезные трудности.

Вклад российского туризма в ВВП страны всегда был невысоким (в 2013-2014 гг. примерно 2 \%), но за 2015-2016 гг. снизился до 1,6\%. В высокоразвитых странах многоотраслевой экономики, таких как Италия и Швейцария, доля туризма в стоимости ВВП составляет 11-12\%, во Франции и Дании - 7-8 \%, в
США и Великобритании - 5 \%. Занятость населения России в туристском секторе $1,5 \%$, тогда как в развитых европейских странах - от 5-7 до 11-13\%.

По данным круглого стола UNWTO 23.11.2016, путешествия могут позволить себе не более $26 \%$ российских граждан [8]. По статистике Ростуризма, путешествует в РФ еще меньшее число жителей - 23 \% граждан, причем вывозится за рубеж в 2-3 раза больше средств, чем остается в стране.

За период кризиса в РФ изменились реалии и тенденции, соотношение трех основных видов туризма. Это обусловило главную цель представленного исследования - проанализировать факторы и особенности, динамику и географию развития международного выездного, международного въездного и внутреннего туризма в России в условиях кризисного этапа развития экономики 2014-2016 годов. Изучение каждого вида туризма представляется крайне актуальным и интересным.

\section{Международный выездной туризм}

Число международных выездных туристов в России за годы кризиса в условиях экономических санкций резко сократилось. Максимальных значений число российских туристов, выехавших за границу, достигло в относительно экономически благоприятном 2013 г. - 18,291 млн [13]. В 2014 г., в условиях 
осложнившейся экономической ситуации, сокращение выездного потока российских туристов было еще не столь велико - на $4 \%$, и число туристов уменьшилось до 17,612 млн. В 2015 г. произошел обвал рынка выездного международного туризма - «минус» $31,3 \%$, и было совершено 12,107 млн поездок. Это самое значительное падение выезда за последние 18 лет [2].

Соответственно, доля выездного туризма по сравнению с въездным и внутренним резко снизилась. На протяжении всей новой истории России международный выездной туризм преобладал над въездным (табл. 1), достигнув пика в 2013 г., когда это соотношение составляло почти $7(6,86)$ : 1. Разница в 2015 г. между этими двумя видами туризма стала гораздо меньше - соотношение $4(4,12): 1$. С одной стороны, увеличение роли въездного туризма это положительный аспект - рост валютных поступлений в страну. Но негативно то, что идет оно не за счет значительного роста въездного туризма, а за счет колоссального сокращения числа выездных туристов.

Причин снижения показателей выездного российского туризма, как и туризма в целом, много. Одной из основных является резкое уменьшение доходов населения. По дан- ным исследования «Потребительский индекс Иванова» аналитиков инвестподразделения «Сбербанка» CIB, средний класс в России сократился за 2015-2016 гг. на 14 млн человек. При незначительном росте заработных плат порог дохода для попадания в средний класс в 2016 г. - 38 тыс. руб. на одного человека. Еще два года назад эта цифра составляла 31 тыс. рублей [12]. Подтверждает эти данные исследование Global Wealth Report банка Credit Suisse, в соответствие с выводами которого с середины 2015 г. по середину 2016 г. благосостояние российских домохозяйств уменьшилось на $14,4 \%$ на каждого взрослого [6]. В такой ситуации именно расходы на отдых и туризм опережающими темпами уменьшаются. Жители тратят средства на первостепенные нужды - покупку продуктов питания, оплату услуг жилищно-коммунального хозяйства, здравоохранение. В лучшем случае выбирают более дешевый турпродукт. А в связи с произошедшим обвалом курса рубля международные выездные туристы еще стремительнее стали переориентироваться на участие во внутреннем туризме.

Не способствовали желанию путешествовать за границу и осложнившаяся геополитическая ситуация в мире, локальные вой-

Таблииа 1

Въезд в Россию иностранных туристов и выезд за границу российских граждан с целью туризма (тыс. поездок)

\begin{tabular}{|c|c|c|}
\hline Годы & $\begin{array}{c}\text { Число прибытий } \\
\text { иностранных туристов в } \\
\text { Россию }\end{array}$ & $\begin{array}{c}\text { Число выездов российских } \\
\text { граждан за границу } \\
\text { с целью туризма }\end{array}$ \\
\hline 2000 & 2215 & 4252 \\
\hline 2001 & 2052 & 3972 \\
\hline 2002 & 2686 & 4426 \\
\hline 2003 & 3152 & 5640 \\
\hline 2004 & 2861 & 6557 \\
\hline 2005 & 2385 & 6785 \\
\hline 2006 & 2433 & 7753 \\
\hline 2007 & 2213 & 9369 \\
\hline 2008 & 2295 & 11314 \\
\hline 2009 & 2100 & 9555 \\
\hline 2010 & 2134 & 12605 \\
\hline 2011 & 2336 & 14495 \\
\hline 2012 & 2570 & 15332 \\
\hline 2013 & 2665 & 18291 \\
\hline 2014 & 2583 & 17612 \\
\hline 2015 & 2937 & 12107 \\
\hline
\end{tabular}

Примечание. Составлено авторами по данным Российского союза туриндустии, Федерального агентства по развитию туризма, Пограничной статистики и материалам сайта www.ratanews.ru. 
ны, военные конфликты, теракты. Создание средствами массовой информации многих западных стран из России «образа врага» привело в ряде государств к негативному отношению к российским туристам местных жителей, и это негативное отношение туристы из России не желают на себе ощущать.

Усугубило ситуацию и то, что в ответ на уменьшение потока туристов туроператоры сняли многие вылеты из регионов, убрали предложения некоторых направлений, что еще больше сократило возможность для жителей провинциальной России поучаствовать в выездном туризме [5, с. 55]. А после ноября 2015 г., когда были закрыты основные для россиян страны международного туризма - Египет и Турция, спад в выездном туризме приобрел катастрофические масштабы.

Соответственно, за годы кризиса резко изменилась география стран-лидеров по приему российских туристов (табл. 2).

Достаточно бюджетные по стоимости, с недолгим авиаперелетом и с наличием системы All-inclusive, Турция и Египет до конца 2015 г. оставались лидерами по въезду туристов из России, хотя и с серьезными потерями по числу приезжающих. Остальные страны первой десятки также менялись незначительно, лишь изменив позиции в рейтинге. Во всех без исключения государствах число россиян значительно уменьшилось - в среднем в 2 раза. Обращает внимание на себя изменение позиции Германии, которая хоть и потеряла российских туристов, но эти потери были не столь велики (260 тыс.), как в других стра- нах, и это позволило стране подняться с 8-го на 4-е место в рейтинге. Это говорит, прежде всего, о том, что Германию посещают не столько участники рекреационного и экскурсионного видов туризма, которые в первую очередь отказываются от путешествий в условиях осложнившейся экономической ситуации, а туристы, выезжающие с деловыми, научными, образовательными целями, которые и в период кризиса продолжают выезжать за границу.

Отсутствие Финляндии в первой десятке в 2015 г. обусловлено резко выросшим курсом евро, при котором жителям Северо-Запада России, составляющим прежде основной поток краткосрочных туристов в эту страну в силу географической близости и особого визового режима, уже не выгодно стало выезжать туда с целями шоппинга. Финляндию в первой десятке стран-лидеров по приему туристов из России заменил Кипр, являющийся одним из самых бюджетных направлений для российского туризма, введший упрощенный порядок получения виз россиянами, с благожелательным отношением к туристам из России.

За пределами первой десятки наименьшие потери по приему туристов из России в 2015 г. по сравнению с 2014 г. демонстрировали относительно недорогие и безвизовые Вьетнам (-5 \%), Черногория (-7\%), которые, соответственно, в рейтинге поднялись и заняли 14-е и 16-е места.

Чтобы хоть как-то удержать ситуацию с провалом выездного туризма под контролем,

Таблича 2

Первая десятка стран-лидеров по выезду российских граждан за границу с целью туризма

\begin{tabular}{|c|l|c|l|c|l|c|}
\hline \multirow{2}{*}{$\begin{array}{c}\text { № } \\
\text { п/п }\end{array}$} & \multicolumn{2}{|c|}{2013 г. } & \multicolumn{2}{c|}{2015 г. } & \multicolumn{2}{c|}{ б мес. 2016 г. } \\
\hline & Страна & Тыс. поездок & \multicolumn{1}{|c|}{ Страна } & Тыс. поездок & Страна & Тыс. поездок \\
\hline 1 & Турция & 3078,6 & Турция & 2665,8 & Таиланд & 370,8 \\
\hline 2 & Египет & 1909,2 & Египет & 1838,6 & Испания & 267,5 \\
\hline 3 & Греция & 1175,6 & Испания & 580,8 & Китай & 254,1 \\
\hline 4 & Китай & 1067,5 & Германия & 571,0 & Кипр & 246,4 \\
\hline 5 & Таиланд & 1034,9 & Греция & 528,6 & Германия & 228,8 \\
\hline 6 & Испания & 1012,8 & Таиланд & 504,4 & Италия & 226,4 \\
\hline 7 & Финляндия & 904,7 & Италия & 481,4 & Греция & 218,6 \\
\hline 8 & Германия & 830,9 & Китай & 417,2 & ОАЭ & 184,9 \\
\hline 9 & Италия & 725,8 & Кипр & 408,6 & Тунис & 173,6 \\
\hline 10 & ОАЭ & 653,4 & ОАЭ & 356,2 & Болгария & 161,9 \\
\hline
\end{tabular}

Примечание. Составлено авторами по данным: $[9 ; 10]$. 
в течение 2015 г. туроператоры прилагали значительные усилия. В первую очередь, решая проблему перераспределения российских туристов, а особенно пляжно-рекреационных, потерявших Турцию и Египет, по другим схожим относительно бюджетным направлениям. Огромное внимание было уделено продвижению турпродукта стран Европы (Кипра, Греции, Болгарии, Испании), Ближнего Востока (Иордании и Израиля), Африки (Туниса, Марокко), Южной, Восточной и Юго-Восточной Азии (Индии, Шри-Ланка, Таиланда, Вьетнама) [4, с. 177-179]. Скачки цен и потоков туристов в представленных регионах создали возможность поучаствовать в «битве» за российских туристов и другим более экзотичным, далеким и дорогим направлениям, в первую очередь странам Латинской Америки (Доминикане, Кубе, Мексике) [3, с. 79].

Усилия не оказались напрасными, и показатели первого полугодия 2016 г. (это пока последние существующие официальные статистические данные) демонстрируют несколько изменившуюся картину выездного туризма россиян. При продолжившемся снижении турпотока это падение составило $28 \%$, тогда как за аналогичный период 2014 г. - 34 \%, так что ситуация в принципе улучшается. С января по июнь за границу с целью туризма было совершено 3 млн 970,5 тыс. поездок [9].

Резко изменилась география выезда российских туристов. Впервые в истории Таиланд занял первую строчку рейтинга, послужив в своем роде заменой пляжных Турции и Египта. Подъем сравнительно недорогих Китая, Кипра, вхождение в первую десятку Туниса с 28-го места и Болгарии с 14-го места - это также ситуация перехвата турецких и египетских туристов. Необходимо отметить, что многие пляжные направления по сравнению с первым полугодием 2015 г. прибавили очень значительно: Тунис - рост $671,1 \%$, Иордания (544 \%), Марокко (277,4 \%), Доминикана $(167 \%)$, Грузия (118 \%), Китай с о. Хайнань $(62,5 \%)$, Таиланд (45\%), Индия с Гоа (42\%), Болгария (30\%), Греция $(23,6 \%)$, Вьетнам (22 \%).

Направления, которые позиционируются, прежде всего, как экскурсионные, понесли потери: Великобритания (-20\%), Германия (-19,5\%), Австрия (-18,7\%), Сербия (-17,7\%), Финляндия
(-15\%), Чехия (-13\%), Франция (-12,5 \%) [9]. Это связано и с дороговизной путешествий по Европе в условиях нынешнего курса евро к рублю, и с тем, что экскурсионные поездки по приоритетности уступают пляжно-рекреационным. Семьи с детьми стараются выехать на море. Если будет возможность путешествовать еще раз, то возможны и экскурсионные туры, а если нет, то экскурсионные поездки откладываются до улучшения экономической ситуации.

Анализ рынка выездного международного туризма в России в целом показал, что ситуацию с выездным туризмом несколько спасает то обстоятельство, что в туризме участвуют в большом процентном соотношении высокодоходные группы россиян. Достаточно обеспеченные жители России и в условиях кризиса не отказываются от участия в выездном туризме, а покупают более дешевые туры или перераспределяют свой бюджет, оставляя приоритетом туризм. А для небольшого сегмента очень высокообеспеченных россиян кризисные явления в экономике России вообще никак не повлияли на их туристские предпочтения.

\section{Международный въездной туризм}

Россия на протяжении всей новой истории никогда не была страной, привлекательной для значительного числа иностранных туристов. 2-2,5 млн иностранных туристов в год с начала XXI в. - это совсем неподобающее развитие въездного туризма для государства с такой территорией, численностью населения и богатейшим туристским потенциалом. Число прибытий иностранных туристов в Россию начиная с 2010 г. увеличивалось (табл. 1), но рост был незначительный. По данным Росстата, в относительно благополучном 2013 г. иностранными туристами было совершено 2 млн 664,8 тыс. поездок в Россию, на 3,7 \% больше, чем в 2012 году. Фактически это - показатель первого десятилетия XXI в., то есть значительной положительной динамики особенно не наблюдалось [10]. В 2014 г. было некоторое снижение иностранного турпотока, но в 2015 г. число приехавших в РФ иностранных туристов выросло довольно значительно - на 13,7 \% за год. Въезд ино- 
странных туристов достиг максимального значения с 2003 года. Кроме того, в годы кризиса впервые в современной истории РФ рост въездного туризма обогнал рост выездного, то есть можно говорить о некотором оживлении этого вида международного туризма, о переломе ситуации.

Факторов, благоприятствующих развитию въездного туризма на современном этапе, несколько. Важнейший - за счет падения курса рубля туризм в России стал финансово доступным многим категориям населения, и появилась возможность удовлетворить существующий в мире интерес к России. Москва даже вошла в десятку самых доступных по стоимости отдыха городов мира для посещения по рейтингу британского издания Тhe Telegraph. Наблюдался рост туристов из стран европейского региона, например, средний прирост в 2015 г. по сравнению с 2014 г. по Испании, Италии, Франции составил 10 \% в год. Но не только жителям благополучных высокоразвитых стран стало дешевле путешествовать по России, но и жителям других регионов мира. Во многом этот результат был достигнут за счет азиатского рынка, в первую очередь китайских, южнокорейских, израильских, а также иранских туристов. Для ряда стран Россия отменила визовые барьеры, например, для Бразилии, Мексики, Аргентины.

В ряде городов и регионов РФ сформировалась неплохая туристическая инфраструктура и конкурентоспособный сервис. Продвижению России как туристской страны способствует популяризация ее разнообразных уникаль- ных нестандартных брендов - например, «“наземного" космического туризма» и др.

За кризисные годы в экономике РФ география стран-лидеров по въезду иностранных туристов в Россию изменилась незначительно, но абсолютные данные по числу путешествующих изменились (табл. 3 ).

Если сравнивать предкризисный 2013 г. и кризисный 2015 г., то сразу обращает внимание, что сократилось число туристов из европейских государств и США. Экономические санкции и видение в России политического «врага» не способствуют росту туристских посещений. В первой десятке исключение составляет лишь Испания, которая отличается спокойным политическим фоном, отсутствием враждебного отношения к России и продолжает наращивать взаимонаправленные потоки туристов. Но в 2015 г. сильно прибавили неевропейские страны. Турция до ноябрьских событий имела значительный прирост по сравнению с 2014 г. на 15,6 \%, но к концу года он упал до минимальных $3,4 \%$ [1].

За первое полугодие 2016 г. первая десятка изменилась незначительно. Лишь по уже названным причинам ее покинула Турция с колоссальным спадом в 91 \%. В первую десятку вошла соседская Финляндия. Азиатские рынки продемонстрировали значительный рост: Иран (+98 \%), Индия (+59\%), Южная Корея (+34,5 \%), Китай (+34\%), также как и европейские страны, хоть и в основном с меньшими показателями - Эстония, Швейцария, Латвия, Франция, Италия [1]. Эти страны и сформировали основу второй десятки по рас-

Таблица 3

Въезд иностранных туристов в Россию

\begin{tabular}{|c|c|c|c|c|c|c|}
\hline \multirow{2}{*}{$\begin{array}{l}\text { № } \\
\text { П/П }\end{array}$} & \multicolumn{2}{|c|}{2013 г. } & \multicolumn{2}{|l|}{2015 г. } & \multicolumn{2}{|c|}{6 мес. 2016 г. } \\
\hline & Страна & $\begin{array}{c}\text { Тыс. } \\
\text { поездок }\end{array}$ & Страна & $\begin{array}{c}\text { Тыс. } \\
\text { поездок }\end{array}$ & Страна & $\begin{array}{c}\text { Тыс. } \\
\text { поездок }\end{array}$ \\
\hline 1 & Германия & 380,3 & Китай & 677,6 & Китай & 274,8 \\
\hline 2 & Китай & 372,3 & Германия & 358,1 & Германия & 141,3 \\
\hline 3 & США & 197,3 & США & 165,1 & США & 73,4 \\
\hline 4 & Великобритания & 157,8 & Турция & 139,3 & Южная Корея & 60,1 \\
\hline 5 & Турция & 122,7 & Израиль & 127,4 & Израиль & 55,9 \\
\hline 6 & Италия & 117,9 & Южная Корея & 116,3 & Великобритания & 51,7 \\
\hline 7 & Франция & 96,9 & Великобритания & 114,5 & Франция & 48,6 \\
\hline 8 & Финляндия & 93,8 & Италия & 109,4 & Италия & 45,4 \\
\hline 9 & Израиль & 92,5 & Франция & 86,8 & Финляндия & 30,6 \\
\hline 10 & Испания & 70,2 & Испания & 79,4 & Испания & 22,4 \\
\hline
\end{tabular}

Примечание. Составлено авторами по данным: [1; 10]. 
сматриваемому показателю. В целом въезд с целью туризма в РФ за полгода вырос на $10 \%$ по сравнению с аналогичным периодом предыдущего года.

Что касается видов международного въездного туризма, в которых участвуют иностранцы в России, то это в основном экскурсионный туризм. Особенно активно в экскурсионных программах участвуют китайские, южно-корейские, индийские и европейские туристы. Новое веяние времени - иранские туристы все больше осваивают черноморское побережье России, способствуя развитию международного приморского пляжного рекреационного туризма. А вот турпоток делового туризма экономические санкции против России резко сократили.

Нельзя не отметить, что фактором, очень сильно тормозящим развитие въездного туризма, являются крайне низкие затраты на привлечение туристов. По статистике, отдельные страны тратят на привлечение одного туриста до 6 евро, в то время как госзатраты России составляют 2 рубля [8]. Кроме того, визовые препятствия тормозят поток туристов в Россию. Отечественные туроператоры настоятельно предлагают ввести электронные визы или визы по прибытию, а также безвизовый 72-часовой транзит, что позволит увеличить число туристов из некоторых стран на $30-40 \%$.

\section{Внутренний туризм}

Внутрироссийский туризм - это тот вид туризма, доходы от которого не перераспределяются между странами, поставляющими и принимающими туристов, а полностью остаются в национальной экономике России, тем самым способствуя, в том числе, и дальнейшему развитию туристской отрасли. Отрадно то, что данный вид туризма в период кризиса испытывал серьезный рост. Статистика потоков внутренних туристов в России крайне несовершенна, но с «высоких трибун» звучат цифры порядка 40 млн участвующих в туристских поездках по России. По заявлению главы Ростуризма Олега Сафонова, внутренний туризм в России за лето 2016 г. вырос на $15 \%$ по сравнению с летом 2015 года. И прогнозируется приблизительно такой же рост внутреннего турпотока и по итогам всего 2016 года [11]. Уже сейчас можно предположить, что 2016 г. для внутреннего туризма стал лучшим в новейшей истории России. Основной причиной такой ситуации является перераспределение в значительной мере с началом кризиса в условиях обнищания населения России туристического спроса с выездного рынка на внутренний. Перераспределение российских туристов из Турции и Египта, а это свыше 4 млн поездок ежегодно, во многом увеличило число внутренних туристов.

Еще одна серьезная причина - в условиях санкций ограничения на зарубежные поездки для ряда российских бизнесменов, политиков, военных. А это группа населения - привыкшая к путешествиям, и их переориентация на внутренние путешествия способствовала росту во внутрироссийском туризме сегмента дорогостоящего VIP-туризма.

В изменившихся политических и экономических условиях произошел широкий выход на внутренний рынок крупных туроператоров, которые ранее занимались в основном только международным туризмом. С этим фактором во многом связан рост дотирования пассажирских авиаперевозок, что способствовало удешевлению туров. За последние годы в России появились новые объекты туристского интереса. Два важнейших направления - это присоединение Крыма с его высокоразвитой инфраструктурой туризма и создание инфраструктуры в Сочи к Олимпиаде 2014 года.

В 2016 г. статистика итогов туристской деятельности вполне обнадеживающая, в частности, турпоток в Крым вырос на 22 \%, посещаемость Краснодарского края увеличилась на 20-25\%.

К сожалению, много факторов, негативно влияющих на развитие внутреннего туризма в РФ. Специфика внутреннего туристического рынка такова, что увеличение спроса, а в данном случае спроса на внутренний турпродукт, всегда способствует поднятию цены на составляющие индустрии туризма - услуги отелей, объектов питания, транспорта. В среднем цены на гостиницы поднимаются на 8$10 \%$ в год, что нормально и закономерно, но есть и прецеденты поднятия цен до $30 \%$, что сразу сдерживает турпоток. 
Не всегда есть согласованная политика развития туризма в отношении основных туристических брендов. Мало взаимопонимания между участниками «отдельных звеньев» туристского бизнеса - музеями, отелями, транспортными средствами, предприятиями питания. Была полностью разрушена и до сих пор не восстановлена сфера социального туризма. А зачастую только этот вид туризма доступен для небогатых жителей страны.

Предполагаемое введение курортного сбора, против которого высказывались практически все туроператоры, также фактор негативный. Тем не менее поручение правительству разработать схему введения нового налога дал глава государства В. Путин. Выдвинул данную инициативу Ставропольский край, где сконцентрированы санаторно-курортные учреждения, в которых более $90 \%$ турпотока - это организованный туризм. Но на многих территориях, в том числе и на самых посещаемых черноморских и крымских курортах, более $50 \%$ туристов едет в частный сектор, с которого собрать курортный сбор крайне затруднительно. Сумма курортного сбора даже 150 рублей за сутки пребывания достаточно высока именно для небогатых туристов, останавливающихся в частном секторе, поэтому введение сбора может «выбросить» из туристского потока значительную долю этого сегмента туризма.

Локализованность туризма - еще одна проблема географии российского туризма. По настоящему регионов, где туристская отрасль приносит существенные доходы в бюджет, единицы - Москва, Санкт-Петербург и их области, города Золотого кольца, Краснодарский, Ставропольский края, Алтай, некоторые республики Кавказа и несколько других территорий. Важнейшая задача - развивать туризм и во всех остальных субъектах Федерации. А это должны быть долгосрочные государственные вложения, причем строго определенные и четко контролируемые. Негативный прецедент уже есть. 30 сентября 2016 г. было опубликовано постановление о «Прекращении деятельности восьми неэффективно функционирующих особых экономических зон в Ставропольском, Хабаровском, Приморском и Краснодарском краях, Мурманской области, республиках Алтай, Адыгея и Северная
Осетия - Алания». ОЭЗ в Хабаровском крае и в Мурманской области были портовыми, остальные - туристско-рекреационными. Было предложено оставить, но сократить территорию двух ОЭЗ на Байкале - в Бурятии и в Иркутской области. За 10 лет государство потратило на ОЭЗ 185,8 млрд руб., а эффективность этих территорий была крайне низкой [7]. Преодоление рассмотренных негативных факторов - залог достойного будущего внутреннего туризма в Российской Федерации.

\section{Заключение}

Проведенный анализ туристской отрасли России в условиях кризисного этапа развития экономики 2014-2016 гг. показывает, что три основных вида туризма - международный выездной, международный въездной и внутренний демонстрировали разные тенденции и разную степень сопротивляемости депрессивным явлениям в хозяйственном комплексе страны.

Самое значительное сокращение числа туристов и доли данного вида туризма произошло в секторе выездного международного туризма россиян, сильнее всего зависящего от роста курса доллара и евро по отношению к рублю, снижения благосостояния россиян и изменившейся геополитической ситуации в мире. Значительно изменилась и география рассматриваемого вида туризма.

Рост и в абсолютном, и в относительном выражении продемонстрировали въездной международный туризм и внутренний туризм. Для въездного туризма падение курса рубля, наоборот, явилось положительным аспектом удешевления российского турпродукта и, соответственно, конкурентоспособности России на рынке въездного международного туризма. Этот же фактор способствовал расширению и изменению географии стран, формирующих туристские потоки в Россию, увеличив долю азиатских стран.

Положительной тенденцией последних лет является значительный рост внутреннего туризма. Для экономики страны, безусловно, приоритетнее развитие внутреннего и въездного туризма, когда финансовые средства туристов остаются на территории России или ввозятся в страну из-за рубежа, а не выво- 
зятся вместе с туристом в другие государства. Особенно в современных условиях, когда растет прямое бронирование туристом услуг, когда потребитель для формирования своего путешествия не обращается к услугам основного плательщика налогов в бюджет от туристской отрасли - туроператорам. И это один из наиболее серьезных стратегических рисков и угроза туроператорскому бизнесу как отрасли экономики России.

Ситуация в российском туризме в 20142016 гг. еще раз подтверждает тезис о том, что туризм - это не только отрасль высоких экономических рисков, но и быстро приспосабливающаяся к современным реалиям, изменяющаяся и быстро восстанавливающаяся. С появлением первых признаков относительного оживления российской экономики в конце 2016 г., некоторой стабилизации курса доллара и евро относительно рубля, замедления падения реальных доходов и некоторой психологической адаптации населения России, в туризме сразу начал действовать фактор «отложенного спроса», что подтверждает поток туристов в открытую в конце года Турцию и значительные продажи туров на новогодние праздники 2017 года.

Уже в 2017 г. международный выездной туризм может отыграть свои позиции у въездного и внутреннего. Сработает «колесо туристских приоритетов», когда удорожание поездок внутри страны снова «вытолкнет» туристов за рубеж. Обещают разрешить для туристского посещения Египет, и спрос на это направление уже сформирован. За время без Турции и Египта россияне освоили идентичные новые достаточно бюджетные направления - Таиланд, Кипр, Греция, Гоа в Индии, о. Хайнань в Китае, Вьетнам, а также ранее «ассортиментные» направления - Грузия, Азербайджан, Армения, Иордания, турпоездки в которые будут совершать и в перспективе.

Важнейшей задачей на фоне предполагаемого роста международного выездного туризма станет удержание темпов роста въездного и внутреннего туризма на уровне хотя бы 2015 2016 гг., в идеале, увеличение этих темпов.

\section{СПИСОК ЛИТЕРАТУРЫ}

1. Въезд-2015: низкий рубль сделал свое дело. // RATA news Ежедневная электронная газета Рос- сийского союза туриндустрии. - 2016. - 10 марта. № 4009. - Электрон. текстовые дан. - Режим доступа: http://www.ratanews.ru/news/news_10032016_ 1.stm. - Загл. с экрана.

2. Выездной турпоток из России показал наибольшее падение с 1998 года // RATA news Ежедневная электронная газета Российского союза туриндустрии. - 2016. - 9 марта. - № 4008. - Электрон. текстовые дан. - Режим доступа: http://www. ratanews.ru/ news/news_9032016_1.stm. - Загл. с экрана.

3. Деточенко, Л. В. Латиноамериканский регион - перспективное направление для российских туристов / Л. В. Деточенко, Н. А. Лобанова // Архитектура многополярного мира в XXI в.: экология, экономика, геополитика, культура и образование : сб. материалов Междунар. науч.-практ. конф., г. Биробиджан, 8 апр. 2016 г. : в 3 ч. Ч. 2 / под общ. ред. В. Г. Шведова ; Приамур. гос. ун-т им. Шолом-Алейхема. - Биробиджан : ИЦ ПГУ им. Шолом-Алейхема, 2016. - С. 77-83.

4. Деточенко, Л. В. Меняющаяся региональная география международного выездного пляжно-рекреационного туризма россиян в зимние сезоны 2014-2016 гг. / Л. В. Деточенко // Факторы и стратегии регионального развития в меняющемся геополитическом и геоэкономическом контексте : материалы Междунар. науч. конф. (г. Грозный, 2025 сент. 2016 г.) / под общ. ред. А. Г. Дружинина. Ростов н/Д : Изд-во Южного федер. ун-та, 2016. С. $175-180$.

5. Деточенко, Л. В. Перспективы и география туристского сезона 2015 г. для российских туристов / Л. В. Деточенко // Антропогенная трансформация геопространства: история и современность : материалы II Междунар. науч.-практ. конф., г. Волгоград. - Волгоград : Изд-во ВолГУ, 2015. - С. 55-60.

6. Доходы домохозяйств падают, турпотоки сохраняются. Парадокс или закономерность? // RATA news Ежедневная электронная газета Российского союза туриндустрии. - 2016. - 30 нояб. № 4196. - Электрон. текстовые дан. - Режим доступа: http://ratanews.ru/news/news_30112016_3.stm.Загл. с экрана.

7. Из десяти туристических ОЭЗ правительство оставило лишь две // RATA news Ежедневная электронная газета Российского союза туриндустрии. - 2016. -3 окт. - № 4155. - Электрон. текстовые дан. - Режим доступа: http://www.ratanews.ru/news/ news_3102016_5.stm.-Загл. с экрана.

8. ООН объявила год устойчивого развития туризма, в Москве обсудили проблемы отечественного турбизнеса // Информационная группа «Турпром». Новости туризма. - 2016. 30 нояб. - Электрон. текстовые дан. - Режим доступа: http://www.tourprom.ru/news/34341. - Загл. с экрана. 
9. Пограничная статистика зафиксировала снижение выезда с целью туризма на 28 \% // RATA news Ежедневная электронная газета Российского союза туриндустрии. - 2016. - 12 сент. - № 4139. Электрон. текстовые дан. - Режим доступа: http:// www.ratanews.ru/news/news_12092016_6.stm. -Загл. с экрана.

10. Показатель роста въездного турпотока опустился на уровень 2008 года // RATA news Ежедневная электронная газета Российского союза туриндустрии. - 2014. - 14 марта. - № 3506. - Электрон. текстовые дан. - Режим доступа: http://www. ratanews.ru/ news/news_14032014_2.stm.-Загл. с экрана.

11. Россияне переориентировались на отдых в пределах своей страны // Travel.ru. - 2016. - 1 сент. Электрон. текстовые дан. - Режим доступа: http:// www.travel.ru/news/2016/09/01/255984.html (дата обращения: 11.09.2016). - Загл. с экрана.

12. Средний класс в России за два года мог сократиться на 14 млн человек // RATA news Ежедневная электронная газета Российского союза туриндустрии. - 2016. - 18 окт. - № 4166. - Электрон. текстовые дан. - Режим доступа: http://ratanews.ru/ news/news_18102016_5.stm.-Загл. с экрана.

13. Статистические рекорды 2013 года: три страны перешагнули миллион, Турция - три миллиона // RATA news Ежедневная электронная газета Российского союза туриндустрии. - 2014. 5 марта. - № 3499. - Электрон. текстовые дан. Режим доступа: http://www.ratanews.ru/news/ news_5032014_5.stm.-Загл. с экрана.

\section{REFERENCES}

1. Vyezd-2015: nizkiy rubl sdelal svoe delo [Entry-2015: Low Ruble Has Done Its Job]. RATA news Ezhednevnaya elektronnaya gazeta Rossiyskogo soyuza turindustrii [RATA news Daily electronic newspaper of the Russian Union of Travel Industry], 2016, no. 4009. URL: http://www.ratanews.ru/news/ news_10032016_1.stm. (accessed November 10, 2016).

2. Vyezdnoy turpotok iz Rossii pokazal naibolshee padenie s 1998 goda [Outgoing Flow of Tourists from Russia Showed the Largest Drop since 1998]. RATA news Ezhednevnaya elektronnaya gazeta Rossiyskogo soyuza turindustrii [RATA news Daily electronic newspaper of the Russian Union of Travel Industry], 2016, no. 4008. URL: http:// www.ratanews. ru/news/news 90320161 .stm. (accessed January 9, 2017).

3. Detochenko L.V., Lobanova N.A. Latinoamerikanskiy region - perspektivnoe napravlenie dlya rossiyskikh turistov [The Latin American Region - a Promising Direction for Russian Tourists]. Shvedova V.G., ed. Arkhitektura mnogopolyarnogo mira $v$ XXI v.: ekologiya, ekonomika, geopolitika, kultura i obrazovanie: sb. materialov Mezhdunar. nauch.-prakt. konf., g. Birobidzhan, 8 apr. 2016 g.: v 3 ch. Ch. 2 [The Architecture of Multipolar World in the $21^{\text {st }}$ Century: Ecology, Economy, Geopolitics, Culture and Education: Proceedings of the International Scientific-Practical Conference, Birobidzhan, April 8, 2016: in 3 parts. Part 2]. Birobidzhan, ITs PGU im. Sholom-Aleykhema, 2016, pp. 77-83.

4. Detochenko L.V. Menyayushchayasya regionalnaya geografiya mezhdunarodnogo vyezdnogo plyazhno-rekreatsionnogo turizma rossiyan v zimnie sezony 2014-2016 gg. [The Changing Regional Geography of International Outbound BeachRecreational Tourism of Russians in the Winter Seasons 2014-2016]. Druzhinin A.G., ed. Faktory i strategii regionalnogo razvitiya $v$ menyayushchemsya geopoliticheskom i geoekonomicheskom kontekste: materialy Mezhdunar. nauch. konf. (g. Groznyy, 2025 sent. 2016 g.) [Factors and Strategies for Regional Development in the Changing Geopolitical and GeoEconomic Context: Proceedings of the International Scientific Conference (Grozny, September 20-25, 2016)]. Rostov-on-Don, Izd-vo Yuzhnogo feder. un-ta, 2016, pp. 175-180.

5. Detochenko L.V. Perspektivy i geografiya turistskogo sezona 2015 g. dlya rossiyskikh turistov [Prospects and Geography of the Tourist Season 2015 for Russian Tourists]. Antropogennaya transformatsiya geoprostranstva: istoriya i sovremennost: materialy II Mezhdunar. nauch.-prakt. konf., g. Volgograd [Anthropogenic Transformation of Geospace: the Past and the Present: Proceedings of the $2^{\text {nd }}$ International Scientific-Practical Conference, Volgograd]. Volgograd, Izd-vo VolGU, 2015, pp. 55-60.

6. Dokhody domokhozyaystv padayut, turpotoki sokhranyayutsya. Paradoks ili zakonomernost? [Incomes of Households Fall, Tourist Flows Maintain. The Paradox or Pattern?]. RATA news Ezhednevnaya elektronnaya gazeta Rossiyskogo soyuza turindustrii [RATA news Daily electronic newspaper of the Russian Union of Travel Industry], 2016, no. 4196. URL: http:// ratanews.ru/news/news_30112016_3.stm. (accessed January 30, 2017).

7. Iz desyati turisticheskikh OEZ pravitelstvo ostavilo lish dve [The Government Left Only Two of the Ten Tourist SEZ]. RATA news Ezhednevnaya elektronnaya gazeta Rossiyskogo soyuza turindustrii [RATA news Daily electronic newspaper of the Russian Union of Travel Industry], 2016, no. 4155. Available at: http://www.ratanews.ru/news/news_3102016_5.stm. (accessed January 22, 2017).

8. OON obyavila god ustoychivogo razvitiya turizma, v Moskve obsudili problemy oteche stvennogo turbiznesa [The United Nations has 
Declared the Year of Sustainable Tourism Development. The Problems of the Domestic Tourist Industry Were Discussed in Moscow]. Informatsionnaya gruppa «Turprom». Novosti turizma [Turprom Information Group. Tourism News], 2016. URL: http://www. tourprom.ru/news/34341/. (accessed January 20, 2016).

9. Pogranichnaya statistika zafiksirovala snizhenie vyezda s tselyu turizma na $28 \%$ [Border Statistics Recorded a Decline of Tourism Departures by $28 \%$ ]. RATA news Ezhednevnaya elektronnaya gazeta Rossiyskogo soyuza turindustrii [RATA news Daily electronic newspaper of the Russian Union of Travel Industry], 2016, no. 4139. URL: http:// www.ratanews.ru/news/news_12092016_6.stm. (accessed January 12, 2017).

10. Pokazatel rosta vyezdnogo turpotoka opustilsya na uroven 2008 goda [The Indicator of Tourist Arrivals Growth Dropped to the Level of 2008]. RATA news Ezhednevnaya elektronnaya gazeta Rossiyskogo soyuza turindustrii [RATA news Daily electronic newspaper of the Russian Union of Travel Industry], 2014, no. 3506. URL: http://www.ratanews.ru/news/ news_14032014_2.stm. (accessed March 14, 2015).
11. Rossiyane pereorientirovalis na otdykh $\mathrm{v}$ predelakh svoey strany [Russians Shifted to Vacation within their Own Country]. Travel.ru. URL: http:// www.travel.ru/news/2016/09/01/255984.html. (accessed September 11, 2016).

12. Sredniy klass v Rossii za dva goda mog sokratitsya na $14 \mathrm{mln}$ chelovek [The Middle Class in Russia Could Be Reduced by 14 Million People during 2 Years]. RATA news Ezhednevnaya elektronnaya gazeta Rossiyskogo soyuza turindustrii [RATA news Daily electronic newspaper of the Russian Union of Travel Industry], 2016, no. 4166. URL: http:// ratanews.ru/news/news_18102016_5.stm. (accessed October 18, 2016).

13. Statisticheskie rekordy 2013 goda: tri strany pereshagnuli million, Turtsiya - tri milliona [Statistical Records in 2013: Three Countries Crossed One Million, Turkey - Three Million]. RATA news Ezhednevnaya elektronnaya gazeta Rossiyskogo soyuza turindustrii [RATA news Daily electronic newspaper of the Russian Union of Travel Industry], 2014, no. 3499. URL: http:/ /www.ratanews.ru/news/news_5032014_5.stm. (accessed March 5, 2015).

\section{Information About the Authors}

Liliya V. Detochenko, Candidate of Sciences (Geography), Associate Professor, Department of Geography, Geoecology and Methodology of Teaching Geography, Volgograd State Socio-Pedagogic University, Prosp. Lenina, 27, 400131 Volgograd, Russian Federation, Lillyad@rambler.ru.

Natalya A. Lobanova, Candidate of Sciences (Geography), Associate Professor, Department of Geography, Geoecology and Methodology of Teaching Geography, Volgograd State Socio-Pedagogic University, Prosp. Lenina, 27, 400131 Volgograd, Russian Federation, natlob66@yandex.ru.

\section{Информация об авторах}

Лилия Валерьяновна Деточенко, кандидат географических наук, доцент кафедры географии, геоэкологии и методики преподавания географии, Волгоградский государственный социально-педагогический университет, просп. Ленина, 27, 400131 г. Волгоград, Российская Федерация, Lillyad@rambler.ru.

Наталья Анатольевна Лобанова, кандидат географических наук, доцент кафедры географии, геоэкологии и методики преподавания географии, Волгоградский государственный социально-педагогический университет, просп. Ленина, 27, 400131 г. Волгоград, Российская Федерация, natlob66@yandex.ru. 